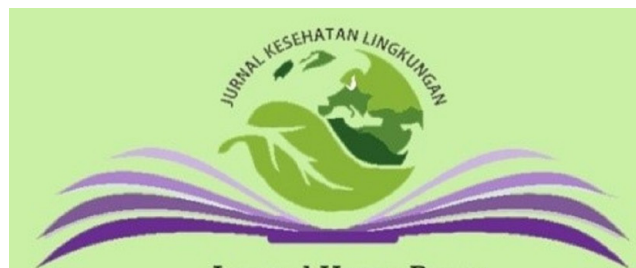

Journal Home Page:

https://e-journal.unair.ac.id/JKL

\section{Jurnal Kesehatan Lingkungan}

Vol. 13 No. 1

DOI: 10.20473/jkl.v13il.2021.9-16

ISSN: 1829 - 7285

E-ISSN: 2040 - 881X

\title{
ENVIRONMENTAL MANAGEMENT STRATEGY TO CONTROL AIR GERMS IN TJITROWARDOJO DISTRICT HOSPITAL
}

Juni Praptiwi ${ }^{1 *}$, Setyo Sri Rahardjo ${ }^{2}$, Sunarto Sunarto ${ }^{3}$

${ }^{1}$ Doctoral Program of Environmental Science, Universitas Sebelas Maret, Jl. Ir. Sutarmi No. 36A Kentingan, Surakarta 57162, Indonesia

${ }^{2}$ Medicine Faculty, Universitas Sebelas Maret, Jl. Ir. Sutarmi No. 36A Kentingan, Surakarta 57162, Indonesia

${ }^{3}$ Faculty of Mathematics and Natural Sciences,, Universitas Sebelas Maret, Jl. Ir. Sutarmi No. 36A Kentingan, Surakarta 57162, Indonesia

\section{Corresponding Author*:}

juni.praptiwi@gmail.com

\section{Article Info}

Submitted

: 11 August 2020

In reviewed

6 November 2020

Accepted

28 December 2020

Available Online

: 31 January 2021

Keywords : Environmental factors, air germs, patient rooms, management strategy

Published by Fakultas Kesehatan Masyarakat Universitas Airlangga

\begin{abstract}
Introduction: The presence of air germs in the hospital patient rooms is potentially to cause health problems for patients. This study aimed to identify andanalyze environmental factors associated with air germs, and formulate environmental management strategi to control air germs in the patient rooms. Methods: This study was an observational analytic survey, used a mixed method and a cross sectional design. Data collection was conducted through laboratory tests and interviews. Data was analysed by pearson correllation test to analyze environmental factors associated with air germs. The appropriate environmental management strategies was determined through SWOT analysis (Strength, Weakness, Opportunities, Threats). Results and Discussion: Several factors related to air germs were temperature $(p=0.032)$, lighting $(p=0.01)$ and the staff knowledge $(p=0.001)$. Humidity was not significantly related to air germs $(p=0.178)$, The results of SWOT analysis indicated that aggressive strategies (Strengths and Opportunities) were arranging internal hospital policies regarding to air quality management based on the Ministry of Health, utilizing educational qualifications and knowledge of room staff to support policy implementation, improving the performance of outsourcing personnel in cleaning services and maintaining hospitals infrastructure, increasing Inhouse Training activities. Conclusion: Environmental factors play an important role in the presence of air germs in the patient rooms so appropriate environmental management strategies are needed to control the presence of air germs.
\end{abstract}




\section{INTRODUCTION}

A healthy hospital environment which is protected from pollution, is very important to support the patient's treatment process. The environment quality must be monitored and maintained considering that hospital is a high potential risk area for human health and environment. Air is one of the environmental components that plays very important role in the survival of living things (1). The presence of bacteria in the air of hospital room comes from biological and non-biological materials (2). Humans breathe $10 \mathrm{~m}^{3}$ of air every day and about $85 \%-90 \%$ of their life is spent indoors. Air inhaled by humans contains microorganisms known as bioaerosol, solid particles or liquid droplets in the air, which contains viruses, bacteria, fungal spores, bacterial endospores, pollen or plant tissue fragments (3). Bioaerosol which contains pathogenic microorganisms inhaled by patients may worsen the patient's health condition.

Different types of microorganisms have different modes of transmission. There are three main routes of transmission, through air, direct and indirect contact (4). One type of microorganism can be transmitted through more than one route. For example, a disease that is currently spreading called coronavirus disease was transmitted through direct contact or by sufferers droplet. A research stated that the coronavirus (Covid19) has become the largest pandemic affecting 210 countries in the world (5). The recent outbreak of pandemic diseases caused by the coronavirus affecting people around the world to worry because the transmission process is very fast and the death rate is quite high, including transmission that occurs in health care facilities. A study in Wuhan 2020 at two hospitals found that the number of samples infected with SARS-CoV-2 RNA taken indoors was higher than those outdoors and the risk was lower in well-ventilated, opened, and away from the crowd areas (6). A research conducted in Eastern Iran stated that out of 14 air or bioaerosol samples taken indoors in hospital wards, two air samples were positive for SARS-CoV-2 so that presence in indoor air could be a potential source of SARS-CoV-2 transmission (7). The incidence of virus infection is often related to the concentration of particles that pollute the air (6). For this reason, efforts to create a healthy, clean, safe and comfortable hospital must be implemented to prevent the spread of pathogens in the hospital environment.

Another case that has not been resolved in hospitals or health care facilities is the incidence of nosocomial infections or currently known as Healthcare Associated Infections (HAls). Healthcare Associated Infections or infectious diseases in health facilities is a world health problem which became the main discussion at the Asian Pacific Economic Comitte (APEC) meeting and the Global Health Security Agenda (GHSA) with the highest case occurring in poor and developing countries (8). According to WHO, it was found that $9 \%$ of nosocomial infections in the world or about 1.4 million patients treated were recorded as cases of nosocomial infection (9). WHO data showed that $15 \%$ of inpatients was exposed to HAls and $4-56 \%$ as the cause of neonatal death with $75 \%$ of cases in Southeast Asia and Sub-Sahara Africa (10). A study showed that $39-60 \%$ nosocomial infections occur in Indonesia (11). The most common nosocomial infections was Surgical Wound Infection (SWI) or Surgical Site Infection (SSI).

Based on data of "dr. Tjitrowardojo" District Hospital in Purworejo Regency in 2018, the number of nosocomial infections, especially Surgical Site Infection was $5.93 \%$. The standard permitted for the incidence of nosocomial infection is $<1.5 \%$ (12). This figure exceeds the standard, so that improvement efforts is needed, because it endangers patients and hospital operations continuity. The incidence of nosocomial infections will increase the cost and duration of patient care and cause death (10). The results of air quality test in the Operating Room of "dr. Tjitrowardojo" District Hospital in 2018 include Room $1=84 \mathrm{CFU} / \mathrm{m}^{3}$, Room $3=100$ $\mathrm{CFU} / \mathrm{m}^{3}$, Room $4=90 \mathrm{CFU} / \mathrm{m}^{3}$. These results were not appropriate to air quality standard requirements in the Ministry of Health of Republic Indonesia. Regulation of Ministry of Health of Republic Indonesia No. 7 Year 2019 about Environmental Health of Hospital, namely the number of germs in operating room air is $10 \mathrm{CFU} / \mathrm{m}^{3}$ (13). Air germs in the hospital environment as the result of transmission from patients with infectious diseases through aerosol droplets spread in the air (2). One of factor causing hospital infection is due to inappropriate hospital environment condition, which causes a high number of room air germs. This study aimed to identify and analyze environmental factors associated with air germs in the patient's room and then to determine environmental management strategies to control the number of air germs in the patient rooms.

\section{METHODS}

The research was carried out from January to March 2020 at "dr. Tjitrowardojo" District Hospital, Purworejo Regency, Central Java Province. This research was an observational analytic surve, with mixed methods research (a combination of quantitative and qualitative methods) and a cross sectional design. The use of mixed methods was intended to complete the description of the result and to strengthen research analysis (14). 
The target population were all hospitals in Purworejo Regency, while the source population was in the patient rooms of "dr. Tjitrowardojo" District Hospital. The sampling point was in the patient room where none of air germ measurement was taken before. It was important to notice the potential of infection or disease transmission. The research used purposive sampling technique. Samples of abiotic and biotic factors were taken in the VVIP, VIP, Class1, Class 2, and Class 3 rooms with a total of 15 points and taken in 2 repetitions so the total number was 30 samples. The sample of social factors was the level of knowledge of staff. The number of room attendant respondents was determined using the Slovin formula, so that out of 227 samples 70 respondents were obtained.

Abiotic factor samples include temperature, humidity and lighting. Thermohygrometerwas used to measure temperature and humidity. Luxmeter was used to measure room lighting. Biotic factor samples were air germs in the patient care room. The sampling procedure was based on the Ministry of Health of Republic Indonesia. Ministerial Decree of Ministry of Health of Republic Indonesia No. 1335/MENKES/SK/X/2002 about Operational Standards for Taking and Measuring Hospital Room Air Quality Samples (15). The method used in sampling the number of room air germs was the Microbiological Air Sampler (MAS) method, as a tool used to calculate the number of indoor air microbes, in units of $\mathrm{CFU} / \mathrm{m}^{3}$. The air quality standard was based on the Regulation of Ministry of Health of Republic Indonesia No. 7 Year 2019 about Environmental Health of Hospital, temperature parameters: $22-24^{\circ} \mathrm{C}$, humidity: $45-60 \%$, lighting: 100 - 200 lux, and the number of air germs: $200-500 \mathrm{CFU} / \mathrm{m}^{3}$ (13). Measurement of social factors used a questionnaire that has been tested for validity and reliability, the knowledge level category divided into less, moderate, and good. Collecting data to support the determination of management strategies included conducting interviews with key persons consisting of the Head of the Environmental Sanitation Installation, Facility Maintenance Installation, the Hospital Infection Prevention and Control Team, the Infection Prevention Control Nurse (IPCN) and the hospital janitor coordinator.

The data were analyzed using the Pearson correlation test to identify and analyze the correlation between the independent and dependent variables. the analysis of interviews result was carried out with SWOT analysis (Strength, Weakness, Opportunities, Threats) in order to find strategies of environmental management in the hospital. In this analysis, internal and external factors will be identified in order to obtain the value of the SWOT analysis. Based on the results of SWOT analysis, the target management strategies were determined according to the existing conditions.

\section{RESULTS}

\section{Samples Characteristics}

Based on the data obtained, the temperature was $16.7 \%$ meet the requirements and $83.3 \%$ did not meet the requirements. The temperature of treatment room at the time of measurement ranged from $22-31^{\circ} \mathrm{C}$. The result of humidity measurement was $52-75 \%$. Lighting parameters that meet the requirements were $43.3 \%$ and $56.7 \%$ did not meet the requirements. The results of light intensity measurement reached $45.27-157.57$ lux. The level of staff knowledge was mostly good as $93.1 \%$ and the moderate level was $6.9 \%$. Most of the respondents were $94.4 \%$ in productive age. Microbiological parameters in the form of air germs were $30 \%$ according to quality standards and $70 \%$ not according to quality standards. the lowest number of air germs measurement were 100 $\mathrm{CFU} / \mathrm{m}^{3}$, while the highest were $7,280 \mathrm{CFU} / \mathrm{m}^{3}$.

Table 1. Variable Frequency Distribution

\begin{tabular}{lcccc}
\hline \multicolumn{1}{c}{ Variable } & Mean & SD & Min & Max \\
\hline $\begin{array}{l}\text { The number of room air } \\
\text { germs CFU/m }{ }^{3}\end{array}$ & 1289.0 & 1439.3 & 100.0 & 7280.0 \\
\hline Temperature $\left({ }^{\circ} \mathrm{C}\right)$ & 28.0 & 2.6 & 22.0 & 31.0 \\
\hline Humidity $(\%)$ & 67.3 & 5.9 & 52.0 & 75.0 \\
\hline Lighting (lux) & 98.9 & 26.9 & 45.3 & 157.6 \\
\hline Officials knowledge scores & 23.6 & 1.5 & 20.0 & 27.5 \\
\hline
\end{tabular}

Table 2. Characteristics of Respondents

\begin{tabular}{lcc}
\hline \multicolumn{1}{c}{ Variable } & N & \% \\
\hline Sex & 70 & 100.0 \\
Male & 12 & 17.1 \\
Female & 58 & 82.9 \\
\hline Education Level & 70 & 100.0 \\
High School & 6 & 8.6 \\
Diploma 3 & 29 & 50.0 \\
Diploma 4/S1 (Undergraduate) & 33 & 97.1 \\
S2 (Graduate) & 2 & 82.9 \\
\hline Age & 70 & 100 \\
$<25$ years old & 7 & 10.0 \\
25-45 years old & 59 & 84.3 \\
$>$ 45 years old & 4 & 5.7 \\
\hline
\end{tabular}

Table 3. Percentage of Measurement Results for Environmental Factor Parameters

\begin{tabular}{lcc}
\hline \multirow{2}{*}{ Variable } & \multicolumn{2}{c}{ Percentage (\%) } \\
\cline { 2 - 3 } & Qualified & Unqualified \\
\hline Temperature $\left({ }^{\circ} \mathrm{C}\right)$ & 16.7 & 83.3 \\
\hline Humidity $(\%)$ & 16.7 & 83.3 \\
\hline Lighting (lux) & 43.3 & 56.7 \\
\hline The number of Air Germs $\left(\mathrm{CFU} / \mathrm{m}^{3}\right)$ & 30.0 & 70.0 \\
\hline Officials Knowledge & Good $=96.7$, Moderate $=3.3$, \\
\end{tabular}




\section{Correlation Between Variables}

The results of bivariate analysis using the Pearson correlation test showed that several factors related to air germs were temperature $(p=0.032)$, lighting $(p=0.010)$, and staff knowledge $(p=0.001)$, while humidity was not related to air germs $(p=0.178)$, but humidity had a strong positive correlation with temperature $(p=0.000)$ and lighting $(p=0.31)$.

Table 4. Results of Person Correlation Analysis

\begin{tabular}{lcc}
\hline \multicolumn{1}{c}{ Independent Variable } & $\mathbf{r}$ & $\mathbf{p}$ \\
\hline Temperature $\left({ }^{\circ} \mathrm{C}\right)$ & 0.393 & 0.032 \\
\hline Humidity $(\%)$ & 0.252 & 0.178 \\
\hline Lighting (lux) & 0.461 & 0.010 \\
\hline Officials Knowledge & -0.595 & 0.001 \\
\hline
\end{tabular}

\section{Strategy Analysis}

In finding the right strategy formulation according to existing conditions so that it could be applied, a SWOT analysis was carried out. The SWOT analysis consists of an analysis of internal and external factors and the results of the scoring of these two factors can be seen in the following table:

Table 5. Internal Factor Analysis (IFAS) and External Factor Analysis (EFAS)

\begin{tabular}{|c|c|c|c|}
\hline Strength $(S)$ & Weight & Rank & WxR \\
\hline Standardized Educational Qualification & 0.20 & 2 & 0.40 \\
\hline Good knowledge levels of the officials & 0.30 & 3 & 0.90 \\
\hline $\begin{array}{l}\text { The availability of unit to maintain and } \\
\text { monitor the quality of hospital environment }\end{array}$ & 0.30 & 4 & 1.20 \\
\hline $\begin{array}{l}\text { Internal Socialization Events (inhouse } \\
\text { training) }\end{array}$ & 0.20 & 4 & 0.80 \\
\hline $\begin{array}{c}\text { Total } \\
\end{array}$ & 1.00 & & 3.30 \\
\hline Weakness $(W)$ & Weight & Rank & $\mathbf{W x R}$ \\
\hline $\begin{array}{l}\text { Officials Awareness in hand hygiene and } \\
\text { waste management }\end{array}$ & 0.27 & 1 & 0.27 \\
\hline Unqualified treatment room design & 0.23 & 2 & 0.46 \\
\hline $\begin{array}{l}\text { Lack of availability of hospital } \\
\text { infrastructures supporting air quality } \\
\text { management }\end{array}$ & 0.27 & 1 & 0.27 \\
\hline $\begin{array}{l}\text { Monitoring of the physical environment } \\
\text { and air microbiology. }\end{array}$ & 0.23 & 2 & 0.46 \\
\hline Total & 1.00 & & 1.46 \\
\hline Total of Strength - Weakness & & & 1.84 \\
\hline Opportunities (O) & Weight & Rank & WxR \\
\hline $\begin{array}{l}\text { There is a regulation in the form of the } \\
\text { Minister of Health's Decree on Hospital Air } \\
\text { Quality Management }\end{array}$ & 0.30 & 3 & 0.90 \\
\hline $\begin{array}{l}\text { The performance of outshorching } \\
\text { personnel in cleaning services and hospital } \\
\text { infrastructures maintenance. }\end{array}$ & 0.35 & 4 & 1.40 \\
\hline Hospital Accreditation Demand & 0.35 & 4 & 1.40 \\
\hline Total & 1.00 & & 3.7 \\
\hline
\end{tabular}

\begin{tabular}{lccc}
\hline \multicolumn{1}{c}{ Threats $(\boldsymbol{T})$} & Weight & Rank & WxR \\
\hline $\begin{array}{l}\text { Lack of awareness of visitors in personal } \\
\text { and environmental hygiene }\end{array}$ & 0.31 & 1 & 0.31 \\
\hline A decreased level of public trust & 0.31 & 2 & 0.62 \\
\hline An increased incidence in hospital infection & 0.38 & 1 & 0.38 \\
\hline Total & 1.00 & & 1.31 \\
\hline
\end{tabular}

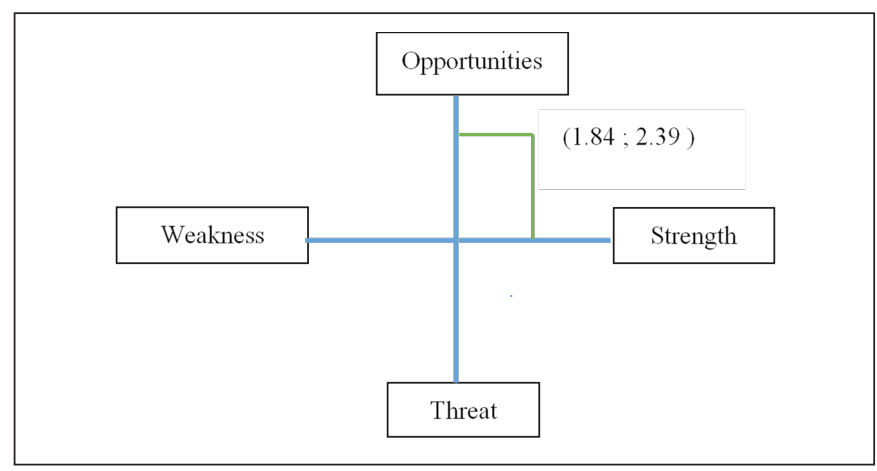

Figure 1. Quadrant Position of SWOT Analysis

Based on the table, the quadrant position is found in quadrant 1 (Strength - Opportunities) with the following values: $(1.84 ; 2.39)$ which is an aggressive strategy. All strengths are utilized properly so that the existing opportunities can be obtained maximally. The result of strategy formulation including the preparation of internal hospital policies regarding air quality management based on the ministerial decree of Ministry of Health of the Republic Indonesia, implementation of established policies, improvement of outsourcing personnel performance in cleaning services and hospital infrastructure maintenance, awareness of the hospital community by Inhouse Training activities, implementation of air quality monitoring and fulfillment of infrastructure for air quality management.

\section{DISCUSSION}

This study indicated that the presence of air germs in patient rooms was influenced by several environmental factors. The number of microorganisms in the treatment room can be influenced by the conditions of temperature, humidity, and room lighting (16). The results showed that temperature was positively correlated with air germs $(p=0.032)$, meaning that the higher the room temperature, the higher the air germs. These results are in accordance with previous research revealed that room temperature conditions will affect the presence of airborne microbes (1). Humidity was not directly correlated with air germs $(p=0.178)$. This is supported by a research 
which states that humidity is not related to the presence of microbes in the air (17). Although humidity was not related to the number of air germs, humidity had a strong positive correlation with temperature $(p=0.000)$. Each microorganism requires different temperatures, such as minimum, optimum, or maximum temperature according to the microorganism conditions. The quality of the indoor environment is influenced by the temperature conditions and air flow ventilation (18). Temperature of $26.5-29.5^{\circ} \mathrm{C}$ and humidity of $64.5-85 \%$ are favorable conditions for the survival and reproduction of microorganisms, while the undesirable conditions are temperatures of $20-22^{\circ} \mathrm{C}$ and humidity of $30-60 \%$ (3).

There are more than 1,400 species of infectious organisms that are known to be pathogenic to humans and capable of causing disease in animals and plants (19). Staphylococcus aureus and Staphylococcus albus are the most commonly bacteria that cause infections in hospitals (20). The most bacteria in the ICCU Room at Bengkulu Hospital is Acinetobacter (2). A study showed thattemperature of $28^{\circ} \mathrm{C}$, Aspergillus grew well (21). Another study stated that Streptococcus sp. and Enterobacter cloacae can grow optimally at $37^{\circ} \mathrm{C}(22)$.

At the research location, the patient rooms for class 2 and class 3 were not air-conditioned, but it had fan installed to keep the room not too hot and humid. Actually the use offan is not good for indoor air quality because it will scatter dust and bioaerosol in the room. It was proven that the number of air germs exceeded the specified standards in class 2 and 3 patient rooms that. This statement could be strengthened by previous research that the number of microbes in nonair conditioning rooms was greater than the number of microbes in air-conditioned patient rooms (23). the visitation hours was observed, showed an increase in the number of occupants so that the activities were also dense and the air circulation was not smooth and stuffy. This condition has potential to increase room temperature and humidity and the number of air germs. This is in line with research states that high levels of human activity and behavior of opening and closing doors have a major influence on the air quality of the operating room (24).

Good air circulation in the room requires adequate ventilation so that fresh air exchanged. The need for indoor ventilation in a good hospital is $15 \%$ of the floor area (25). In non-air conditioning rooms, for smooth air circulation, windows and ventilation should be maximally open during the day. However, in this study there were several windows in the non-air conditioning room which position was closed so the air circulation is not smooth, there was no change in clean air in the room. In a study, stated that the air flow in the room was influenced by the difference in temperature and air pressure because the air would flow from a place with a higher temperature and pressure to a lower temperature through ventilation holes and windows (26). Lack of indoor air exchange will lead to accumulation of indoor air contaminants which can cause health effects, such as building related illness (BRI) and sick building syndrome (SBS) (27). SBS is a result of trapped air pollutants and higher humidity levels indoors (28).

Temperature and humidity are two interrelated factors which, if they are not in accordance with the standard, will cause a high number of air germs. The increasing of humidity causes the increased microbial content because the cells on the surface are moved by water particles (1). Adequate ventilation is required to stabilize indoor air conditions. It is necessary to add electric ventilation as well as a combination of natural and electric in the room with lack of natural ventilation. Installation of exhaust fans is very helpful for air exchange, but in research location, there is no installation of exhaust fan in each patient room. Air conditioning systems must be designed with a standard installation design, equipped with sound absorbers, air intake and exit control systems, special filters, disinfectants resistance so that easy to clean and rust resistant (29). the unproperly maintained of HVAC (heating, ventilation, and air conditioning) system will make microbial contamination worse and cause disease transmission (30).

The correlation between lighting and air germs in the patient care rooms is shown by the value of $p=0.010$ with a positive correlation which means thatthe higher light intensity, the higher presence of air germs. This study is in line with previous studies stated that there was a significant correlation between lighting and the number of air germs (17). Sunlight is very beneficial for life. The warmth of the morning sun is more comfortable for our bodiesthan day light. therefore it is highly recommended that morning sunlight can penetrates into the room. Inadequate sunlight penetration into the room will cause microbial growth and a lack of natural lighting. A dark room due to lack of sunlight has the potential for germs (16). UV light emitted at a wavelength of $254 \mathrm{~nm}$ is able to deactivate germs by damaging their DNA (30).

In this study, showed that $65 \%$ of the treatment rooms used artificial lighting, room with closed windows had less sunlight penetration and therefore less effective in killing germs. Strategies to brighten the room ischoosing bright colors of walls, floors and furnitures, installing a drop ceiling, lowering the ceiling position and adding lights (25). Simple ways to a better lighting in non-air conditioning room is opening the windows and curtains wide, while for an air-conditioned room, opening the 
windows and the curtains in the morning when sunlight appearsai least once a day. Lighting can affect patient comfort and help hospital staff carry out all activities in caring patients (31).

Environmental management strategy, based on SWOT analysis, suggest to carry out routine monitoring of parameters and then evaluated for improvement. Patient rooms are equipped with air quality monitoring devices so that it can be checked and read immediately. An information board is provided in each room regarding the required temperature, humidity and lighting standards so that it can be read by every staff. Improving the air circulation system and adding ventilation includes installing exhaust fan in each patient room. The activities are adjusted to the guidelines that have been regulated by the central government, and then the hospital compiles policies according to the conditions and capabilities they have.

The next research variable is the staff knowledge. The results showed that the knowledge of staff was related to the number of room air germs with a negative correlation $(p=0.001)$, meaning that the better the knowledge level of thestaff, the lower room air germs. Staff with good knowledge will try to provide good service to patients. Having high knowledge can foster positive behavior and increase awareness of staff in an effort to prevent infection (32). The staff will keep the room clean, comfort the room atmosphere, maintain personal hygiene but staff with low level of knowledge will be less concerned about various things including environmental cleanliness and personal hygiene which impact the high number of air germs in the treatment room. In a study, explained that knowledge is not enough. It must be supported by changing habits, ways of thinking and innovations that make progress (33). The knowledge level is influenced by the education level so that a person can understand, learn something, and shape a perspective and mindset (34).

Hand hygiene is an example of good behavior and needs to be improved because it is the main method in preventing hospital infections (35). staff who have good knowledge will also carry out routine hand hygiene. Based on the monitoring data of the Hospital Infection Prevention and Control Team in January 2020, the compliance of care room staff in hand hygiene reached $85 \%$, the standard was $100 \%$, meaning that there were still $15 \%$ did not comply with hand hygiene. The results showed that the level of staff knowledge was good, but not all staff had implemented good actions and practices because there were still staff who had not complied with hand hygiene. Increasing the implementation of hand hygiene can reduce the incidence of contamination in the work area from $32 \%$ to $8 \%$ which in turn can reduce the incidence of nosocomial infections (4).

A study stated that the transmission or spread of germs could be caused by unhealthy and unclean behavior of staff while providing services to patients (35). Thus, education and personal hygiene monitoring, especially the hand hygiene of staff, should be carried out regularly. Hand washing has been proven as an effort to prevent the spread of infection (33). Provision of hand hygiene facilities will also support the staff compliance properly. Various studies have reported that adherence to hand hygiene significantly reduced the number of Methicillin-Resistant Staphylococcus Aureus (MRSA) infections in various hospital units (36).

The strategy can be applied in overcoming problems related to the knowledge level of staff is holding In House Training on environmental management for hospital and outsourcing staff, especially those related to hospital air quality management. In house training activities will periodically increase the level of knowledge and behavior of staff. Janitors are given the latest knowledge and practices on how to clean environment that does not cause aerosols and aseptics and to use recommended disinfectants in accordance with scientific and technological developments in health and environmental fields. The policies formulated and established by the hospital must be implemented by all hospital staff.

\section{ACKNOWLEDGEMENT}

The author would like to thank the Ministry of Health of the Republic of Indonesia, the Agency for the Development and Empowerment of Health Human Resources as providing assistance for the college educational costs of health human resources and all parties who helped the research process.

\section{CONCLUSION}

Environmental factors have an important role in the presence of air germs in the patient room. Each environmental parameter is connected each other most of the parameters of temperature, humidity, and room lighting still exceeded the standards required in the ministerial decree of Ministry of Health of the Republic Indonesia, while most of the staff knowledge level or $96.7 \%$ was good. In order to optimize environmental conditions, it is necessary to make an effort to manage the hospital environment properly. alternative strategy is offered to solve the problem of high air germs in patient rooms, namely environmental management on controlling the number of air germs in patient rooms. The hospital internal policy formulation program includes 
implementing of established policies, improving the performance of outsourcing personnel in cleaning services and maintenance of hospital air management facilities, increasing awareness of the hospital community with inhouse training activities, implementing programmed air quality monitoring and fulfilling the facilities and infrastructure for air quality management. In this study, the samples used were limited and had not yet examined. other researchers are suggested to use more samples and identify the bacteria.

\section{REFERENCES}

1. Mayasari A, Zulkarnain, Agrina. Analisis Lingkungan Fisik Udara Terhadap Angka Kuman Udara di Rumah Sakit. J IImu Lingkung. 2020;13(1):81-89. https://jil.ejournal.unri.ac.id/index.php/JIL/article/ view/7905/6211

2. Santri $P$, Yunus $M$, Taurina $H$. Angka dan Pola Bakteri Penyebab Healthcare-Associated Infections ( HAls ) pada Udara di Ruang Intensive Cardiac Care Unit ( ICCU ) Rumah Sakit Umum Daerah ( RSUD ) dr. M. Yunus Bengkulu. J Kedokt Raflesia. 2018;4(1):1-14. https://ejournal.unib.ac.id/index. php/jukeraflesia/article/view/6882

3. Gizaw Z, Gebrehiwot M, Yenew C. High Bacterial Load of Indoor Air in Hospital Wards: The Case of University of Gondar teaching Hospital, Northwest Ethiopia. Multidiscip Respir Med. 2016;11(1):1-7. https://mrmjournal.biomedcentral. com/articles/10.1186/s40248-016-0061-4

4. Jaichenco AL, Lima LC. Infectious Disease Considerations for the Operating Room. Sixth Edit. A Practice of Anesthesia for Infants and Children. United States: Elsevier Inc; 2019. https://doi. org/10.1016/B978-0-323-42974-0.00050-1

5. Paital B. Nurture to Nature via COVID-19, a Self-Regenerating Environmental Strategy of Environment in Global Context. Sci Total Environ. 2020;729(139088):1-11. https://doi.org/10.1016/j. scitotenv.2020.139088

6. Carraturo F, Del Giudice C, Morelli M, Cerullo V, Libralato G, Galdiero E, et al. Persistence of SARS-CoV-2 in the Environment and COVID-19 Transmission Risk from Environmental Matrices and Surfaces. Environ Pollut. 2020;265B(11510):1-6. https://doi.org/10.1016/j.envpol.2020.115010

7. Kenarkoohi A, Noorimotlagh Z, Falahi S, Amarloei A, Mirzaee SA, Pakzad I, et al. Hospital Indoor Air Quality Monitoring for the Detection of SARSCoV-2 (COVID-19) Virus. Sci Total Environ. 2020;748(141324):1-10. https://doi.org/10.1016/j. scitotenv.2020.141324

8. Ministry of Health of Republic Indonesia. Regulation of Ministry of Health of Republic Indonesia No. 27 year 2017 about Guidelines for Infection Prevention and Control in Health Care Facilities. Jakarta: Ministry of Health of Republic Indonesia; 2017.

9. Ningsih TA, Iravati S, Nuryastuti T. Angka Kuman di
Ruang Rawat Inap RSUD Dr. M. Haulussy Ambon. Ber Kedokt Masy. 2016;32(6):183-188. https://doi. org/10.22146/bkm.8763

10. Sapardi VS, Machmud R, Gusty RP. Analisis Pelaksanaan Manajemen Pencegahan dan Pengendalian Healthcare Associated Infections di RSI Ibnusina. J Endur. 2018;3(2):358-366. http:// ejournal.Ildikti10.id/index.php/endurance/article/ viewFile/3029/1077

11. Berliana B. Analisa Bakteri Udara Sebagai Upaya Pemantauan dan Pencegahan Infeksi Nosokomial di Rumah Sakit. Husada Mahakam. 2016;4(3):141150. http://husadamahakam.poltekkes-kaltim.ac.id/ ojs/index.php/Home/article/view/10

12. Ministry of Health of Republic Indonesia. Ministerial Decree of Ministry of Health of Republic Indonesia No. 129/MENKES/SK/II/2008 about Minimum Service Standard for Hospital. Jakarta: Ministry of Health of Republic Indonesia; 2008.

13. Ministry of Health of Republic Indonesia. Regulation of Ministry of Health of Republic Indonesia No. 7 Year 2019 about Environmental Health of Hospital. Jakarta: Ministry of Health of Republic Indonesia; 2019.

14. Hadi S. Stok Karbon dan Partisipasi Masyarakat dalam Pengelolaan Hutan Mangrove Teluk Jor Lombok Timur. Thesis. Surakarta: Universitas Sebelas Maret Surakarta; 2019.

15. Ministry of Health of Republic Indonesia. Ministerial Decree of Ministry of Health of Republic Indonesia No. 1335/MENKES/SK/X/2002 about Operational Standards for Taking and Measuring Hospital Room Air Quality Samples. Jakarta: Ministry of Health of Republic Indonesia; 2002.

16. Nugroho DA, Budiyono, Nurjazuli. Faktor-Faktor yang Berhubungan dengan Angka Kuman Udara di Ruang Rawat Inap Kelas III RSUD Dr. Moewardi Surakarta. J Kesehat Masy. 2016;4(4):900-906. https://ejournal3.undip.ac.id/index.php/jkm/article/ view/14385

17. Noya LYJ, Wahyuningsih NE, Joko T. Pemeriksaan Kualitas Udara Ruang yang Berhubungan dengan Angka Kuman di Ruang Operasi Rumah Sakit Sumber Hidup di Kota Ambon 2020. J Kesehat Masy. 2020;8(5):679-68. https://ejournal3.undip. ac.id/index.php/jkm/article/view/27927/24404

18. Dionova BW, Mohammed MN, Al-Zubaidi S, Yusuf E. Environment Indoor Air Quality Assessment Using Fuzzy Inference System. ICT Express. 2020;6(3):185-194. $\quad$ https://doi.org/10.1016/j. icte.2020.05.007

19. Morse SA, Meyer RF. Viruses and Bioterrorism. In: Reference Module in Life Sciences. United States: Elsevier; 2017. https://linkinghub.elsevier.com/ retrieve/pii/B9780128096338110076

20. Palawe B V, Kountul C, Waworuntu O. Identifikasi Bakteri Aerob di Udara Ruang Operasi Instalasi Bedah Sentral (IBS) RSU Prof. Dr. R. D. Kandou Manado. J E-Biomedik. 2015;3(3):827-833. https:// doi.org/10.35790/ebm.3.3.2015.10563 
21. León FMG, Duarte-Escalante E, CalderónEzquerro MDC, Jiménez-Martínez MDC, AcostaAltamirano G, Moreno-Eutimio MA, et al. Diversity and Characterization of Airborne Bacteria at Two Health Institutions. Aerobiologia. 2016;32(2):187198. https://doi.org/10.1007/s10453-015-9389-z

22. Baharutan A, Rares FES, Soeliongan S. Pola Bakteri Penyebab Infeksi Nosokomial pada Ruang Perawatan Intensif Anak di BLU RSUP Prof. Dr. R. D. Kandou Manado. J e-Biomedik. 2015;3(1):412419. https://doi.org/10.35790/ebm.3.1.2015.7417

23. Raimunah R, Lutpiatina L, Kartiko JJ, Norsiah W. Angka Kuman Udara Ruang Rawat Inap Anak dengan dan Tanpa Air Conditioner (AC) di Rumah Sakit. J Skala Kesehat. 2018;9(1):1-8. https://doi. org/10.31964/jsk.v9i1.152

24. Stauning MT, Bediako-Bowan A, Andersen LP, Opintan JA, Labi AK, Kurtzhals JAL, et al. Traffic Flow and Microbial Air Contamination in Operating Rooms at a Major Teaching Hospital in Ghana. J Hosp Infect. 2018;99(3):263-270. https://doi. org/10.1016/j.jhin.2017.12.010

25. Jayanti L, Manyullei S, Bujawati E. Kesehatan Lingkungan Udara Ruang Rawat Inap Rumah Sakit Syekh Yusuf Kabupaten Gowa. Higiene. 2016;2(1):33-40. http://garuda.ristekbrin.go.id/ documents/detail/522028

26. Raharja M. Kualitas Angka Kuman Udara Pada Ruang Persalinan Praktik Bidan Swasta di Kota Banjarbaru. J Apl Tek Kesehat Lingkung. 2015;12(2):284-290. https://doi.org/10.31964/jkl. v12i2.24

27. Robles DD, Kramer SW. Improving Indoor Air Quality Through The Use of Ultraviolet Technology in Commercial Buildings. Procedia Eng. 2017;196(1):888-894. http://dx.doi.org/10.1016/j. proeng.2017.08.021

28. Sattar SA. Indoor Air as a Vehicle for Human Pathogens: Introduction, Objectives, and Expectation of Outcome. Am J Infect Control. 2016;44(9):95-101. http://dx.doi.org/10.1016/j. ajic. 2016.06 .010
29. Tacutu L, Nastase I, Catalina T. A Critical Regard on Romanian Regulations Related to Indoor Environment Quality in Operating Rooms and a Technical Case Study. Energy Procedia. 2016;85(1):511-520. https://doi.org/10.1016/j. egypro.2015.12.237

30. Kanaan M. CFD Optimization of Return Air Ratio and Use of Upper Room UVGI in Combined HVAC and Heat Recovery System. Case Stud Therm Eng. 2019;15(100535):1-9. $\quad$ https://doi.org/10.1016/j. csite.2019.100535

31. Apriyani A, Wijayanti PEH, Habibi M. Pencahayaan, Suhu dan Indeks Angka Kuman Udara di Ruang Rawat Rumah Sakit Tk. IV Samarinda. SUARA FORIKES. 2020;11(2):157-159. http://dx.doi. org/10.33846/sf11211

32. Handayani NLP, Suarjana IK, Rina Listyowati. Hubungan Karakteristik, Pengetahuan dan Motivasi Perawat Dengan Kepatuhan Cuci Tangan di Ruang Rawat Inap RSU Surya Husadha Denpasar. Archieve of Comm Health. 2019;6(1):9-17. https:// doi.org/10.24843/ACH.2019.v06.i01.p02

33. Saint S. Can Intersectional Innovations Reduce Hospital Infection?. J Hosp Infect. 2017;95(2):129134. http://dx.doi.org/10.1016/j.jhin.2016.11.013

34. Hapsari AP, Wahyuni CU, Mudjianto D. Knowledge of Surveillance Officers on Identification of Healthcare-associated Infections in Surabaya. J Berk Epidemiol. 2018;6(2):130-138. http://dx.doi. org/10.20473/jbe.V6I22018.130-138

35. Muntaha R, Caesar DL. Faktor Lingkungan Fisik Ruangan Dengan Angka Kuman Udara Ruang Rawat Inap Gedung Siti Hajar Rumah Sakit Islam Sultan Hadlirin Jepara. J Keperawatan dan Kesehatan. 2016;1(5):97-103. https://doi. org/10.31596/jcu.v1i5.153

36. Cruz JP, Bashtawi MA. Predictors of Hand Hygiene Practice Among Saudi Nursing Students: A Cross-Sectional Self-Reported Study. J Infect Public Health. 2016;9(4):485-493. http://dx.doi. org/10.1016/j.jiph.2015.11.010 